Glaukos' billede i Iliaden - bladene hænger i de store træers yderste grene og rives bort af efterårsstormene.

At verden skulle være vigtigere end menneskelivet - hvilken skandale for os moderne mennesker, for hvem stederne, tingene, elementerne har mistet enhver blivende betydning. Eller er det en historisk konstruktion, der overser de virkningshistoriske spor, som de homeriske fortællinger sammen med alle mulige andre fortællinger fra nær og fjern trækker efter sig? Kan mennesket ikke gøre den erfaring i dag, at tilhørsforholdet til et hus grunder den menneskelige eksistens og udryddelsen af huset åbner en afgrund under den nødstedte? Eller at elementerne er det vi lever af, og som samtidig tager livet fra os i det øjeblik, hvor de griber om sig? Hvis alt er så pokkers moderne og postmoderne, så skulle læseren jo ikke kunne gøre erfaringer ved at træde ind i det homeriske univers, eller også er Homer ligeså moderne som så megen anden litteratur.

Principielt set er det vel også hvad de mest reflekterede af de moderne og postmoderne forfattere siger: Det gælder om at anskue den historiske verden som denne vidtstrakte horisontalitet, der vokser og aftager, hvor der tillige er mange mørke strækninger, men hvor alt grundlæggende er til stede. Hvad der kommer til syne, afhænger naturligvis af hvor man stiller sig i landskabet, der bestandigt veksler i nye overgange og lader noget gå under og andet opstå. Odyssé- en åbner for en verden, som vi deler, idet vi både er adskilt fra den, men samtidig har noget fælles med den. Således er intet umiddelbart fortroligt, men med tiden bliver det enten læseren bekendt, eller også forbliver det én fremmed. Odysséen er for alle, der lever i verden og gør erfaringer. Pas godt på den, giv den videre, for der er kun denne ene.

Jonas Holst Sorensen

\section{David eller Goliat?}

\section{Jeppe Matzen, Israels historie om bolocaust, Akademisk, Kobenhavn, 2002, 136 sider, $168 \mathrm{kr}$.}

Israels historie om holocaust er yderst aktuel i forbindelse med et temanummer om Hannah Arendt. Arendt har som tysk jøde været førstehåndsvidne til jødeforfølgelserne og har også på forskellig vis haft tilknytning til organisationer med forbindelse til den unge israelske stat. Hun har i flere sammenhænge udtrykt holdninger til udviklingen i det unge Israel, nok mest kontroversielt $i$ "Eichmann in Jerusalem: The Banality of Evil", og samtidig har hun været meget kritisk overfor jødernes behandling af palæstinenserne. Disse udtalelser har ganske miskrediteret hende overfor et jødisk-hebræisk publikum, og Mat- 
zens redegørelse for den kollektive erindrings udvikling i Israel kan ses som en sober forklaring på, hvorfor Arendts kritik er blevet så negativt modtaget.

Som baggrundsforståelse for israelernes forhold til palæstinenserne, er bogen også uhyggeligt aktuel. Den militære overlegenhed hos israelerne gør, at deres kompromisløshed overfor den palæstinensiske modstand kan virke absurd; israelernes frygt for palæstinenserne synes at være en omvendt realisering af den gamle historie om David og Goliat, hvor det er israelerne, der er overmagten. Ifølge Matzen er det dog helt andre strukturer end de realpolitiske forhold, der er styrende for, at situationen har udviklet sig som den har. Forklaringen ligger $i$ behovet $i$ forbindelse med den israelske statsdannelse for en central myte til at integrere de forskellige jødiske grupperinger, som kom til landet efter 2 . verdenskrig.

Bogens tese er, at udviklingen af en fortolkning af holocaust, der kan samle disse grupper, er nødvendig for, at Israel kan udvikle sig til en stærk og levedygtig nation (s. 16). Matzen viser, hvordan den officielle (og i starten regeringsbårne) israelske holocaustfortolkning har ændret sig i takt med landets nationale situation, politiske lederskab og befolkningssammensætning.

Eichmann-processen i 1961 og senere
Seksdageskrigen i maj 1967 kommer med dens korte version af historien om "katastrofe og forløsning" til at udgøre afgørende vendepunkter i det officielle Israels erindring om holocaust og bliver fremtidige fikspunkter i dets politiske kultur. Yad Vashem (statsligt oprettet mindested og forskningscenter for holocaust) får styrket sin placering og kommer til at udgøre et officielt udtryk for selve nationens søgen efter sin sjæl via den tragiske arv, som holocaust er. Læren for den jødiske nation er, at israelerne er potentielle ofre og må være beredte til at kæmpe for Israel. Den israelske holocausthistoriografi er således blevet i lige så høj grad en del af fortællingen om den israelske stats tilblivelse, som den er historien om folkemordet på jøderne.

Bogens forord er skrevet af Herbert Pundik, der giver en situationskarakteristik af den aktuelle politiske konfliktsituation mellem palæstinenserne og israelerne. Han melder klart ud. Kritik af den israelske besættelse af de palæstinensiske områder "er ikke blot legitim og berettiget, men også ønskelig, fordi den kan bidrage til, at Israel af hensyn til sine interesser i forhold til udlandet lægger bånd på sig selv" (s. 13-14). Det er en skam, at Matzen er så forsigtig i forhold til dette område. Faktisk er det næsten lykkes ham at skrive sig uden om dette dilemma. Palæstinenserne udgør, trods minoritetsstatus, en aktiv befolkningsgruppe på staten Israels 
område, og de burde have haft en rolle at spille $\mathrm{i}$ en redegørelse for den kollektive bevidstheds udvikling i Israel.

Ovennævnte problem kan siges at ligge implicit i Matzens metode: Matzen er identitetshistoriker og arbejder ud fra et fokus på kollektive erindringer som kilde til historien, og en overbevisning om at en nations identitet udvikles ved, at dens elite bevidst konstruerer en national bevidsthed. Det må medføre en forsimpling af den komplekse masse af forskellige holdninger en befolkning udgør. Hos Matzen er nationen blevet til den jødiske nation, og han trækker i stedet nogle interessante skillelinjer frem mellem de oprindelige jøder i Israel, der før statens oprettelse havde købt jord her, og de holocaustoverlevende. Spørgsmålet er dog, om man kan forstå historien udfra, hvordan intellektuelle og historikere tolker den, og se den løsrevet fra den politiske, strategiske og ideologiske virkelighed.

Tine Petersen 